УДК 159.922.75-053.6

DOI:10.26565/2410-1249-2018-10-08

\title{
THE ROLE OF THE FIXED IMAGINATION IN THE OCCURENCE OF ADDICTION AT ADOLESCENT AGE
}

\author{
Kira Sedykh ${ }^{\dagger \dagger}$ \\ ${ }^{1}$ Poltava V.G. Korolenko National Pedagogical University \\ Ostrogradsky Street, 2, Poltava, 36000, Ukraine \\ ${ }^{\dagger}$ E-mail: sedykhkira@gmail.com, http://orcid.org/0000-0003-3528-7569 \\ Oleksandr Filts ${ }^{2 \dagger \dagger}$ \\ ${ }^{2}$ Danylo Halytsky National Medical University in Lviv \\ Pekars'ka street, 69, Lviv, Lviv region, 79000 Ukraine \\ ${ }_{\dagger}^{\dagger}$ E-mail: pavenckyj.o@gmail.com, http://orcid.org/0000-0002-5350-8305
}

The article contains the description of the phenomenon of fixed imagination as a system-forming element in the personality dependence system. The psychological essence of the influence of the catathymic imagination on personal behavior is determined. The features of the fixed imagination in the formation of dependence on the addictive agent as well as its connection to the process of thinking and emotional and motivational sphere are analyzed. The role of the fixed imagination at different stages of the formation of the addictive process, and the specific features of the fixed imagination as a mechanism of addiction occurrence in adolescence is presented. The psychological role of the ritual of transition as a significant factor in the rehabilitation of addicted individuals is pointed out.

KEY WORDS: fixed imagination, system of addiction, adolescent age, addiction, addictive motivation, imago.

\section{РОЛЬ ФІКСОВАНОЇ УЯВИ У ВИНИКНЕННІ УЗАЛЕЖНЕННЯ В ПІДЛІТКОВОМУ ВІЦІ}

${ }^{1}$ Седих К.В., ${ }^{2}$ Фільц О.О.

${ }^{1}$ Полтавський національний педагогічний університет ім. В.Г. Короленка вул. Остроградського, 2, м. Полтава, 36000, Украӥна

2 Львівський національний медичний університет імені Данила Галицького вулиия Пекарська, 69, Львів, Львівська область, 79000 Україна

Стаття містить опис феномену фіксованої уяви як системоутворюючого елементу системи узалежнення особистості. Визначена роль фіксованої уяви як центру комунікації між іншими психічними процесами: емоціями, пам'яттю, мотивацією та мисленням у становленні залежності. Фіксована уява визначена як емоційно насичений образ, що створюється на основі процесу гіпертрофування частини дійсності в уяві і її добудування у фантазії. Проаналізовані особливості фіксованої уяви у становленні залежності від адиктивиного агенту. Побудована структурно-динамічна модель механізму адикції. Виявлено, що взаємодія емоції і образу розвивається по спіралі і поступово зумовлює фіксацію уявного образу. Визначена психологічна суть впливу кататимно-імагінативного образу на поведінку особисті. Створюється специфічна «амальгама» - сплав емоції $\mathrm{i}$ образу, який набирає самостійного надцінного значення. Представлена роль фіксованої уяви на різних етапах формування адиктивного процесу, специфіка фіксованої уяви як механізму виникнення узалежнення в підлітковому та ранньому юнацькому віці. фіксована уява визначена як та когнітивна інстанція, що створює вихідно «склеєний» амальгамований образ-образ-бажання. Описане значення аддиктивної субкультури на формування узалежнення як ритуалу ініціації. Поставлено питання про вагоме значення фіксованої уяви в процесі реабілітації хімічно узалежнених осіб, ії роль у формуванні і збереженні тверезої поведінки особистості. можливість використання феномену фіксованої уяви для побудови позитивних терапевтичних когнітивно-поведінкових схем. Зазначена психологічна роль ритуалу переходу як вагомий чинник в реабілітації хімічно залежних осіб.

КЛЮЧОВІ СЛОВА: фіксована уява, система адикції, підліток, узалежнення, адиктивна мотивація, імагінативний образ

\section{РОЛЬ ФИКСИРОВАННОГО ВООБРАЖЕНИЯ ПРИ ВОЗНИКНОВЕНИИ ЗАВИСИМОСТИ В ПОДРОСТКОВОМ ВОЗРАСТЕ}

\author{
'Полтавский начиональный педагогический университет им. В.Г. Короленка \\ ул. Остроградского, 2, г. Полтава, 36000, Украина \\ 2 Львовский национальный медицинский университет имени Данила Галицкого \\ ул. Пекарская, 69, Львов, Львовская обл., 79000 Украина
} Статья содержит описание феномена фиксированного воображения как системообразующего элемента системы зависимости личности. Об означена роль фиксированного воображения как центра коммуникации между другими психическими процессами: эмоциями, памятью, мотивацией и мышлением в становлении зависимости. Определена психологическая суть 
влияния кататимно-имажинитивного образа на поведение личности. Проанализированы особенности фиксированного воображения в становлении зависимости от химического агента. Представлена роль фиксированного воображения на разных этапах формирования аддиктивного процесса, специфика фиксированного воображения как механизма возникновения зависимости в подростковом и раннем юношеском возрасте. Обозначена психологическая роль ритуала перехода как важный фактор в реабилитации химически зависимых особ.

КЛЮЧЕВЫЕ СЛОВА: фиксированное воображение, система аддикции, подросток, зависимость, аддиктивная мотивация, имажинитивный образ

Formulation of the problem. In recent years, the problem of addiction and addictive behavior associated with the use of psychoactive substances, the lack of special knowledge and skills of healthy lifestyle, as well as timely socially adaptive strategies of personality exacerbates the issue of psychological and social support for individuals with addiction.

In the studies carried out by domestic and foreign authors A.S. Ayvazova, N.L. Bochkareva, G.D. Zolotova, Ts.P. Korolenko, A.V. Kotlyarov, V.D. Mendelevich, V.M. Orzhehovskaya, G.V. Starshenbaum, S.V. Tolstoukhova, V.I. Shabashnaya, A.F. Shaidulina, I.O. Shishova, E.E. Bechtel, V.C. Biteński, B.S. Bratus, I.P. Lysenko, N.Yu. Maksimova, A.V. Mituhlyaev, P.I. Sidorov, I.K. Sosin, R. Goswick, W.H. Joaves et al., the role of age and personality features of the dependence development was defined; the role of motivation and such mental processes as thinking and emotions has been sufficiently studied. However, the role of imagination in the addiction development has not been dealt with in depth. Analysis of recent research and publications. The majority of authors (A. Yu. Akopov; Korolenko, 1990; A. S. Timofeev; Sapolsky, 2017; Goswick, 1982; Steinberg, 2014; Knutson, 2000) who study the problems of addiction, regard it as one of the forms of destructive behavior, combined with the desire to escape from reality through the use of certain substances and the constant fixation of attention on certain subjects or activities, accompanied by the changes in mental state and the emergence of intense emotions, and their mood. This way, an illusion of solving real problems is created. A similar way of confrontation with reality is fixed in human behavior and becomes a stable strategy for interacting with actuality (Goswick, 1982).

The object of research is the mechanism of addiction development. The subject of study is the role of fixed imagination in the mechanism of addiction development and in rehabilitation.

The aim of this article is toexplore the role of the fixed imagination in addiction development and psychotherapeutic rehabilitation of addicted clients.

The main methods of the research are comparison, analysis, systematization and generalization of general scientific data, as well as phenomenological description of the features of the fixed imagination with further synthesis in theoretical hypothesis form.

Presentation of the main research material. In the emergence of addiction, the underdeveloped mechanisms of adaptation to life are primarily emphasized, which leads to the formation of an addictive attitude as a set of cognitive, emotional and behavioral features (Winehold, 2009; Sedych, 2015). The underdevelopment of these mechanisms creates a significant emotional discomfort, resulting in the individual's search for a specific agent to help them plunge, at least for some time, into an "alternative state". It may be a game, a movie, alcohol, a drug, etc. Since the adjustment mechanisms are not fully developed in adolescence, this age is the most susceptible to the occurrence of addictions.

Adolescence is generally known as one of the most critical stages in the formation of personality. It is characterized by a number of specific features, each of which can be a significant factor in the formation of addictive behavior (Sapolsky, 2017; Sedych, 2015; Goswick, 1982; Knutson et al., 2000; Steinberg, 2014):

- identity crisis;

- an acute passion for communication with the peer group effect;

- protesting against educational authorities;

- stubbornness and a drive to resistance (confrontation),

- ambivalence and paradoxical characterological reactions; 
- a desire for ungrounded independence and separation from the family;

- an increased interest in the unexpected, the unknown, as well as in excessive risk

- a need to solve "metaphysical" and "universal" problems

- a tendency to exaggerate the complexity of problems;

- hedonistic settings of conscience.

All of these features of adolescence are inevitably formed around socially significant forms of addiction (love, sport, art, etc.). At the same time, generalization of emotional phenomena plays an important role. Impressions or images with a common emotional sign, i.e., with a similar emotional influence on a person, have a tendency to combine, despite the fact that there is no connection between them, either by similarity or adjacency. Such combinatory is typical for the processes of imagination taking place in dreams and daydreams. It is noted that this sphere is a special "place" where the intuitive personal values and contents are registered and exist. It is in this quality that the imagery forms cease to be the epiphenomenon of a real practical life of a person. The power of imagination and the superiority of one of the poles (positive or negative) determine the attitude of the individual to the world, or rather, the system of attitudes. It is here that the global personal mechanism is established, setting out either the generalized-intuitive fear of life, the constant expectation of something bad and, accordingly, the desire to prevent failures; or the equally generalized-intuitive expectation of joy and, accordingly, the desire to succeed. In imagination, a certain part of reality is hypertrophied and complemented in fantasy, which creates an emotionally charged image (picture). We define this image as fixed imagination. Let us dwell on the analysis of fixed imagination phenomenon in greater detail.

Imagination is a mental image of something that is not currently presented in perception (does not exist in reality now or has never been existed). Synthesis of representations in the processes of imagination is carried out in various forms: 1) addition; 2) agglutination; 3) accentuation; 4) hyperbolization; 5) schematization; 6) typing. Representations of reality in perception, memory, etc. always unambiguous, i.e., there is only one "picture" of a particular situation or the subject of reality (here we refer specifically to the "picture" elements of consciousness and do not discuss imaginary reconstructions and interpretations) in the mind. In contrast, pictures of imagination are always multiple, i.e., they coexist simultaneously in the mind, within one chronotope - in the form of multiple pictures of imagination arising for the same reason. It is essential that the number of these images is essentially unlimited, except by the strength of individual abilities. The object (the situation) causing the images of the imagination acts as a fact of consciousness and is always uniformly correlated with reality, and is, in fact, a clearly identified fragment of the latter. But it serves only as a pretext for the emergence of imagery and the place of their "concentration" in the mind. This means that a particular reality, although significant for the functioning of the imagination, does not specify the entire content of picture-images. The imagination relies on the reflected instantaneous reality only as an occasion for unfolding of its own pictures. Reality is only the initial material. If in the plane of reflection in the mind the existing and immanent-probabilistic states of the object are fixed, then in the plane of imagination the object is also given to us in fixed, but unlimitedly possible states. It is the possible that exists within the limits of "real possible - unreal impossible" (or in paradoxical terms: from "possibly possible" to "impossibly impossible") without losing its qualitative certainty.

We believe that the system of addiction, which collectively consists of such elements as motivation, emotion, memory, thinking, body and behavior, is united by a special phenomenon of fixation in the imagination, specific for the formation of addictive relationships and ideas. In the course of the forming of the addiction mechanism, it is imagination that plays a central role.

We have created a structural-dynamic model of the addiction mechanism, presented in Fig. 1.

Let us try to describe this mechanism. When the system of addiction is already formed, the trigger for its activation is the object of addiction (e.g., a chemical substance). Reflecting on the communication of the processes of imagination and emotions, the existence of a circular connection between them should be noted. Thus, the pictures of imagination always have emotional coloring; on the other hand, every feeling, 
every emotion tends to be embodied in certain images corresponding to this feeling. Even when they do not have a direct or personal relationship with the real life situation of an individual, they are still vividly experienced as positive or negative. There are significant age differences in the interaction between imagination and emotions. The mechanism of formation of the picture of the imagination in the child occurs in a circle: the image evokes emotion, and emotion generates an image that again generates and strengthens the same emotion (Filts, 2018). This pattern of the image formation, which is characteristic of childhood, is partly preserved in the future, particularly in adolescence, and always occurs when certain images of reality need to be assimilated.

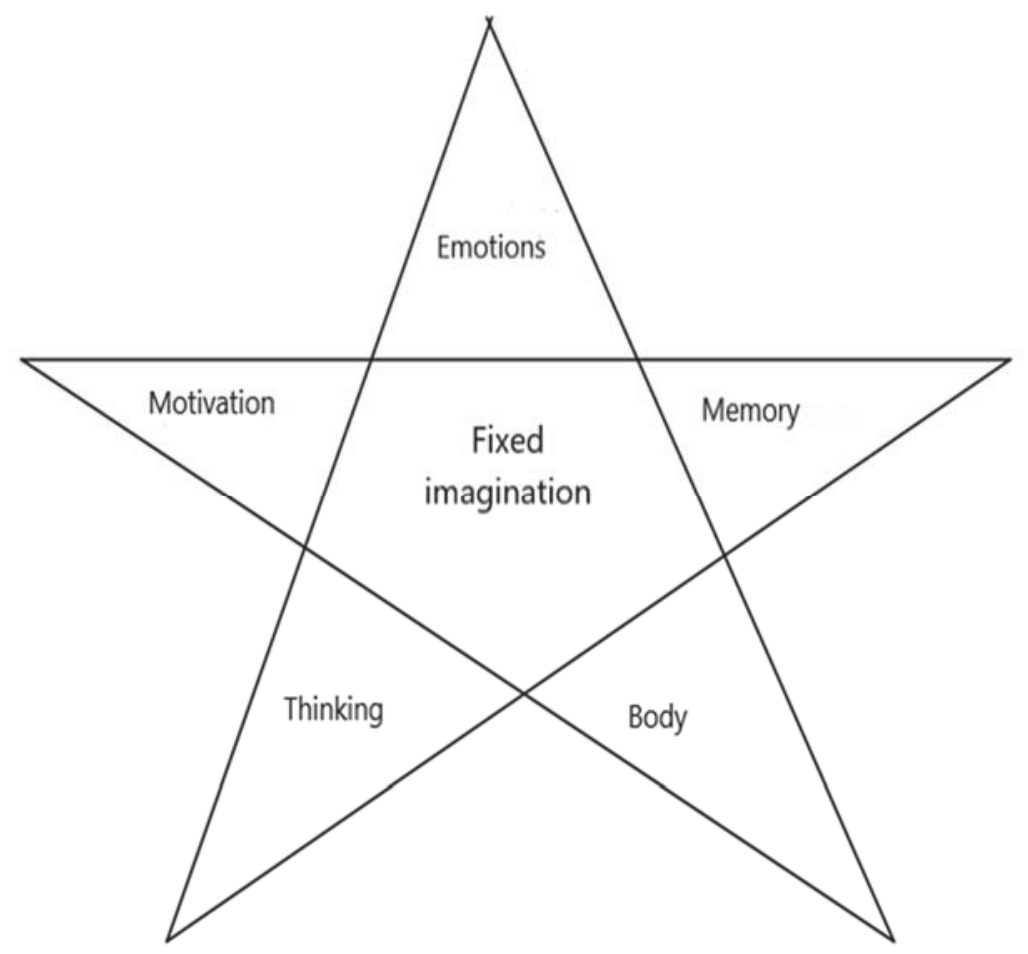

Figure 1. Structural-dynamic model of the mechanism of addiction

In contrast to the formation of the picture of imagination in the child, the formation of the fixed imagination picture takesa spiral form. Thus, in the first stage, the fixed imagination reflects an emotionally intense bond (for example, between the use of an addictive agent and the appearance of a reaction to the use); then - the fixed imagination regulates emotional states and manages perception, memories, etc. It can be said that due to such spiral dynamics the fixed imagination gradually forms the dominant image in conjunction with the overvalued (dominant) idea of addiction. It is this image, along with the dominant idea, that becomes a "regulatory" factor for the inner plan of action and the "programming" of life. (It should be noted that any idea with necessity is of a regulatory nature, since - by definition - its adoption imposes obligations on an individual - that is, motivates them - to facilitate its implementation). At the same time, the domination of overvalued emotional attitude and an overvalued idea regarding the object of addiction is ensured by their affective saturation.

The peculiarity of the regulatory function of an affectively saturated dominant (overvalued) idea is that the realization of this idea, which arises as the fixed imagination, is to be implemented primarily or immediately (the dominant component), as well as "at all costs" (the overvalued component). And this, in essence, is addiction. 
Since, according to the law of the general emotional sign, an emotion is able to pick up impressions, thoughts and images concordant with the mood possessing the individual at the moment, then, in our opinion, it triggers the mechanism of creation of such a phenomenonas fixed imagination. The interaction of emotion and image develops spirally and gradually causes fixation of the imaginary picture. Thus, the emotion clarifies the image; the emotion itself is specified as well, becoming fixed on the refined image. At the next stage secondary experience emerges, arising from these pictures of imagination, and the images themselves become emotionally "charged". A specific "amalgam" is created - an alloy of emotion and an image that gains an independent value.

It is well known that an adolescent's sense of pleasure arises as a result of joining the group, communicating, and receiving unusual cognitive and bodily experience. Further on, this pleasure assimilates separate elements of reality and combines them into a connection stipulated by to the dominant mood from the inside and the corresponding affective experience - but not from the outside, by the logic of these very images. As we have already pointed out, such combinatory is inherent in dreams and daydreams.

Thus, due to the implementation of the motives for communicating with significant peers and the acquisition of their own identity through the feeling of belonging to this group, a catathymic imaginative picture of the "desired object" is created. Each individually or several together, these motivational foundations form the next stage of the system of addiction, namely, the addictive behavior - the sequence of access to the means of addiction is determined. The determined frequency of implementation of the addictive behavior is established, and ritualization of behavior is created.

Subsequently, the entire subculture of dependence becomes a catathymic experience, and an overvalued attitude is formed for both the agent and the entire subculture.

It is important to note that the object of addiction (e.g., a chemical substance) becomes a transitional object of communication, a symbol of the relation and the whole subculture, where rituals outline the boundaries of this subculture.

Researchers of addictive behavior note that in the first stage of the occurrence of addiction there is an experience of acute change in the mental state in the form of feeling of joy, ecstasy, unusual elation, a sense of drama, and risk connected to certain actions (consuming the substances that change the mental state, experience in connection with the risky situation in gambling, etc.), and fixation of this connection in the mind. During communication, endorphins (hormones of pleasure) are secreted biochemically, and thus, in the body and memories, experiences are fixed (the body component of the system of addiction). During the actualization of fixed imagination, endorphins are secreted as well (without an object of desire in the immediate reality). Memories of communication in the group (the role of memory) and substance consummation as a symbol of this communication create a mental (imaginary) image, and then fix, stereotype this image, and form an overvalued image (representation). We believe that a fixed imagination is the very cognitive authority which creates the initially "glued" "amalgamated" image - the image-desire. This image is supported through rituals and conversations about the chemical substance creating an additive subculture and reinforcing it.

Thus, we can say that the beginning of the development of the addictive process occurs at the emotional level (Sapolsky, 2017); however, further development of dependence will only occur with the participation of afixed imagination.

Thus, we described the process of spiral, cyclic formation of a fixed imagination as of a system-forming factor for the unfolding of addictive behavior. Considering a fixed imagination as a factor in the addiction development, we predict that the addictive agent acts as a trigger for the process; a catathymic attachment to the object (e.g., a chemical substance) is developed.

However, speaking about the formation of an addictive behavior in adolescence, the motive for communicating with significant individuals (the reference group), who contribute to the spiral fixation of the fixed imagination, the motive for establishing their own identity plays an important role as well. The development of personal identity takes place via a crisis of transition from adolescence to adulthood. This 
transition requires a certain ritual - initiation - toestablish a conscious identity of the mature person. As A. van Gennep, an anthropologist, has found, in the so-called traditional cultures, rituals of transition always played an important role - rituals that accompanied changes of place, condition, social status, or position. In these rituals, three phases are singled out: 1) separation; 2) margin (limen); 3) reaggregation (cited by (Terner, 1983).

In the modern civilization world, this function of the society (community) of creating emotionally rich rituals of transition is virtually lost. To move to another status in tribal communities, an individual was subjected to specially designed trials and suffering. In our society, parents cannot create such a situation and act as an initiating figure: an outside senior figure is necessary - a mediator (e.g., a priest, a teacher, a guru or a psychotherapist). In search of a new identity, the adolescent is looking for symbolic transition figures; rituals in the subculture of addiction fulfill this symbolic transition function - this is a kind of initiation for a youngster.

In this way, we have the following scheme of the system of addiction: FIXED IMAGINATION APPROBATION IN REALITY - AN OVERVALUED IDEA OF BEHAVIOR PLANNING - BEHAVIORAL RITUAL AS FIXED BEHAVIOR FOR IMPLEMENTATION OF FIXED IMAGINATION. The determined role of the fixed imagination in the process of addiction development allows re-evaluating the share of different mental spheres in the formation of addictive mechanisms, focusing for the first time on the central role of mechanisms of imagination in this process. The defined addiction model provides a new framework for understanding addictive mechanisms and developing a procedure to overcome them in practice.

In our previous publication (Filts, Sedych \& Mychailiv, 2018) we have already described the phenomenon of fixed imagination; in the course of further analysis of the rehabilitation process (a dissertation carried out by S. Mykhailiv and directed by K.V. Sedykh), it became clear that fixed imagination is also significant for the formation and reinforcement of the sober behavior of the individual. This raises the question of the possible existence of the use of these mechanisms for construing either positive or negative therapeutic cognitive-behavioral schemes.

The process of rehabilitation. At this stage, our task was to study the psychological mechanism of rehabilitation of substance-addicted clients while participating in the 12 steps program. The psychological objectives of rehabilitation are obtaining a new status and a new identity through a psychotherapeutic program.

Based on V. Turner's idea about the cultural healing rituals, we determined that the 12-step psychotherapy program, which lasts 28 days in the rehab centers for substance addiction, is in fact a fullfledged healing ritual. Earlier in this article, we have already focused on the significance of implementation of the rituals of transition with changes in the social or psychological status of a person. As M. Chiksentmikhayi notes, all rituals pursue a goal - through the implementation of schematized actions, to restore the order in the individual's mind.

We consider the ritual in the so-called "field context" (V. Turner's term), under specific historical conditions, namely, in the process of rehabilitation. The symbols of the ritual have a synthesizing character, combining heterogeneous and logically incompatible ideas. The second phase of the cultural ritual is called the liminal, i.e., intermediate, threshold. In this phase, the individual receives dual features and the liminal status. Liminal individuals have high tolerance for ambivalence because they can adapt for a long time to the loss of their previous status and place in society.

The sense of liminality in psychotherapeutic clients is a sign of readiness for gaining a new status and a new identity, with the loss of the previous identity and previous meanings.

Consequently, the process of rehabilitation sees an individual through "from the chaos of liminality to the order - the new structure of the personality", from the loss of the social status of a drug addict (alcoholic) to the emergence of a new status - sobriety. Thus, the stages of the passage of the ritual are distinguished: 1. Pre-identity; the previous status. 2. Liminality and the ritual of the Healing. 3. A New identity; a new status.

During the ritual for the transition to a new identity in a substance-addicted individual, it is necessary to create new catathymic-imaginative pictures of the fixed imagination. They start competing with the previous 
images of the FI, e.g., along with the desired addictive object, through the creation of a catathymic-imaginative picture of "the desired self", which is to become dominant in the imagination.

In the formation of the sober individual's lifestyle, the phenomenon of afixed imagination plays an important role through the mechanism of the formation of the catathymic-imaginative picture of "sober success". Thefixed imagination thus serves as the center of communication between other mental processes: emotions, memory, motivation, and thinking.

Conclusions and perspectives of further exploration in this field. Consequently, fixed imagination is the center of communication between other mental processes: emotions, memory, motivation, and thinking. We define afixed imagination as an emotionally chargedimage, which is created on the basis of the process of hypertrophy of the part of reality in the imagination and its completion in fantasy. The interaction of emotion and image develops spirally and gradually causes fixation of the imaginary picture. A specific "amalgam" is created - an alloy of emotion and image that gains an independent value. We see the prospect of further research in theoretical and empirical exploration of the change in the cognitive structures of an individual in the process of rehabilitation of substance-addicted individuals.

\section{REFERENCES}

Filts, O.O., Sedych, K.V, Mychailiv, S.M. (2018). Фіксована уява як механізм виникнення узалежнення [Fixed imagination as an addiction formation mechanism]. Психологія і особистість [Psychology and personality], 2 (14), 9-22. [in Ukrainian].

Goswick, R. (1982). Components of Looneliness During Adolescence. Journal of Youth and Adolescence, 11, 373-383.

Knutson B. et al. (2000). FMRI Visualization of Brain Activity During a Monetary Incentive Delay Task. Neuroimage, $12,20-27$.

Korolenko, C.P., Donskyh, Т.A. (1990). Семь путей к катастрофе. Деструктивные формы поведения в современном мире [Seven ways to disaster. Destructive forms of behavior in the modern world]. Novosibirsk: Nauka [in Russian].

Sapolsky R. (2017). Биология добра и зла. Как наука объясняет наши поступки [Biology of good and evil. How science explains our actions]. Moscow: Alpina non fikshen. [in Russian].

Sedych, K.V. (2015). Делінквентний підліток. Навчальний посібник для студентів вищих навчальних закладів [Delinquent teenager. A manual for students in higher education]. Kyiv: Publishing House «Slovo». [in Ukrainian].

Steinberg L. (2014). Age of Opportunity: Lessons from the New Science of Adolescence. New York: Houghton Miffin.

Terner V. (1983). Символ и ритуал [Symbol and the ritual]. Moscow: Nauka [in Russian].

Winehold, В. (2009). Противозависимость: бегство от близости [Counteraddiction: escaping from intimacy]. Kamianets-Podilskyi: Axioma. [in Russian]. 